2014

\title{
Caddo Ceramic Vessels from the Sipes Hill Site (41RK602) along Martin Creek in the Sabine River Basin in East Texas
}

Timothy K. Perttula

Heritage Research Center, Stephen F. Austin State University

Robert Z. Selden Jr.

Heritage Research Center, Stephen F. Austin State University

Bo Nelson

Heritage Research Center, Stephen F. Austin State University

Follow this and additional works at: https://scholarworks.sfasu.edu/ita

Part of the American Material Culture Commons, Archaeological Anthropology Commons, Environmental Studies Commons, Other American Studies Commons, Other Arts and Humanities Commons, Other History of Art, Architecture, and Archaeology Commons, and the United States History Commons

Tell us how this article helped you.

This Article is brought to you for free and open access by the Center for Regional Heritage Research at SFA ScholarWorks. It has been accepted for inclusion in Index of Texas Archaeology: Open Access Gray Literature from the Lone Star State by an authorized editor of SFA ScholarWorks. For more information, please contact cdsscholarworks@sfasu.edu. 


\section{Caddo Ceramic Vessels from the Sipes Hill Site (41RK602) along Martin Creek in the Sabine River Basin in East Texas \\ Creative Commons License \\ (c) (1) (8)}

This work is licensed under a Creative Commons Attribution-NonCommercial 4.0 International License 


\section{Caddo Ceramic Vessels from the Sipes Hill Site (41RK602) along Martin Creek in the Sabine River Basin in East Texas}

Timothy K. Perttula, Robert Z. Selden, Jr., and Bo Nelson

\section{INTRODUCTION}

The Sipes Hill site (41RK602) is an ancestral Caddo site on Martin Creek, near Trammel's Trace, about $20 \mathrm{~km}$ from its confluence with the Sabine River (Figure 1). It is ca. $2 \mathrm{~km}$ downstream from the Martin Lake dam. The Sipes' Home site (41RK603) is about $100 \mathrm{~m}$ to the northeast.

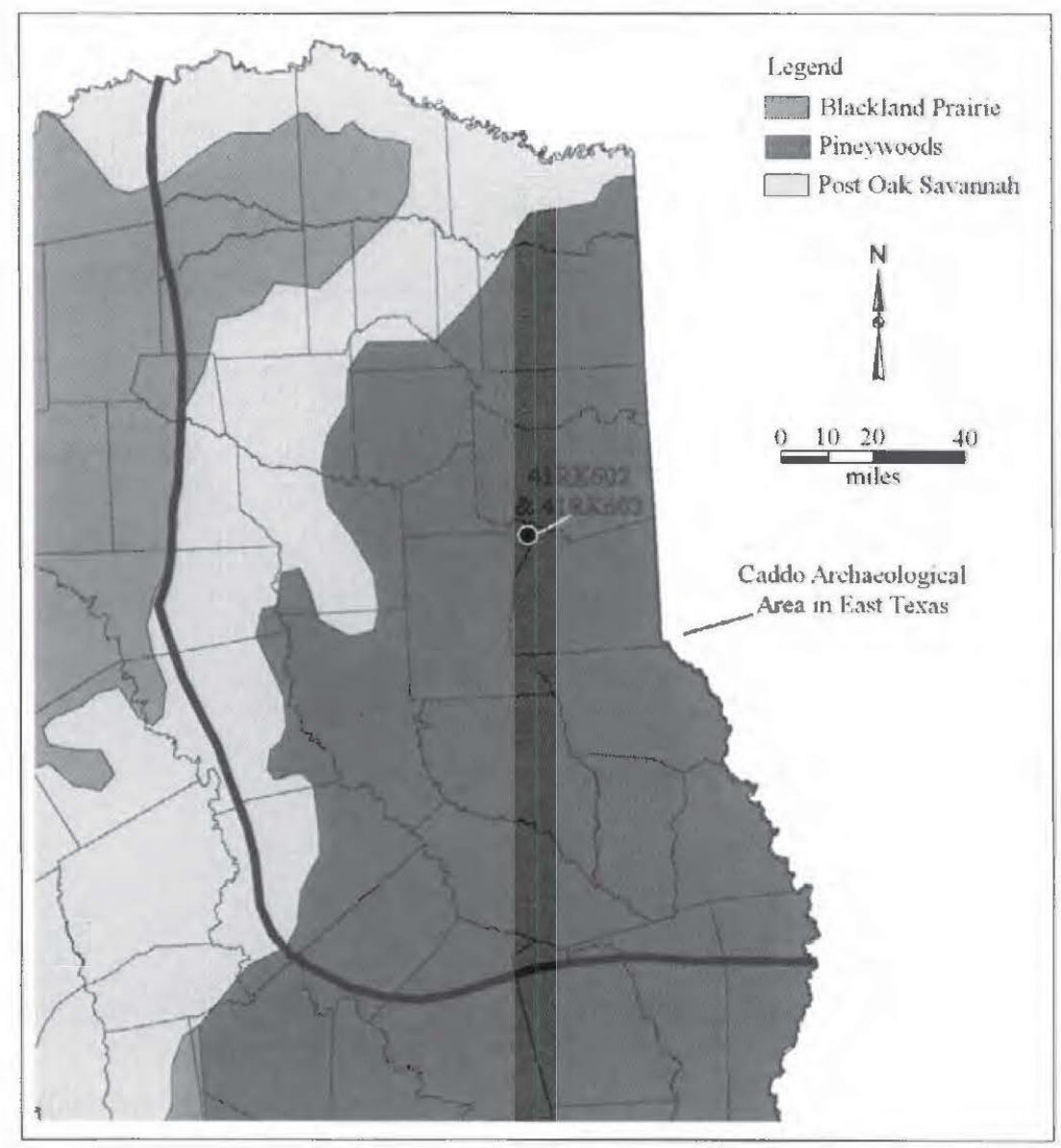

Figure 1. Locations of the Sipes Hill (41RK602) and Sipes' Home (41RK603) sites in East Texas. Figure prepared by Lance Trask.

This site was found and investigated by Buddy C. Jones in the 1950 s or early $1960 \mathrm{~s}$. He did an unknown amount of excavations at the site, and ended up excavating at least one Caddo burial at the site; there are no available notes concerning these excavations or the burial feature, however. Whole vessels from the Sipes Hill site in the Jones collection are at the Gregg County Historical Museum. 


\section{VESSELS}

A total of 10 whole or almost whole ceramic vessels have been documented from the Sipes Hill site. The engraved fine ware vessels are typologically identified as Ripley Engraved, a post-A.D. 1450 fine ware in Titus phase communities in both the Big Cypress and Sabine River basins (Fields and Gadus 2012; Perttula 2012), or at least have stylistic elements commonly seen on Ripley Engraved in the mid-Sabine River basin. This suggests that the Sipes Hill site has a Late Caddo period component (ca. A.D. 1450-1680) that is part of the Pine Tree Mound community (Fields and Gadus 2012:Figure 9.10).

SITE NAME OR SITE NUMBER: Sipes Hill

VESSEL NO.: 2003.08.1715

NON-PLASTICS AND PASTE: grog

VESSEL FORM: Jar

RIM AND LIP FORM: Everted rim and rounded lip

CORE COLOR: F (fired in a reducing environment and cooled in the open air)

INTERIOR SURFACE COLOR: light reddish-brown; fire clouds on the rim

EXTERIOR SURFACE COLOR: light brown; fire clouds on the body and base

WALL THICKNESS (RIM, BODY, AND BASE IN MM):

rim, $4.2 \mathrm{~mm}$; body, $6.3 \mathrm{~mm}$

INTERIOR SURFACE TREATMENT: smoothed

EXTERIOR SURFACE TREATMENT: none

HEIGHT (IN CM): 14.4

ORIFICE DIAMETER (IN CM): 18.8

DIAMETER AT BOTTOM OF RIM OR NECK (IN CM): 18.2

BASE DIAMETER (IN CM) AND SHAPE OF BASE:

6.1 ; circular and flat

ESTIMATED VOLUME (IN LITERS): 1.6

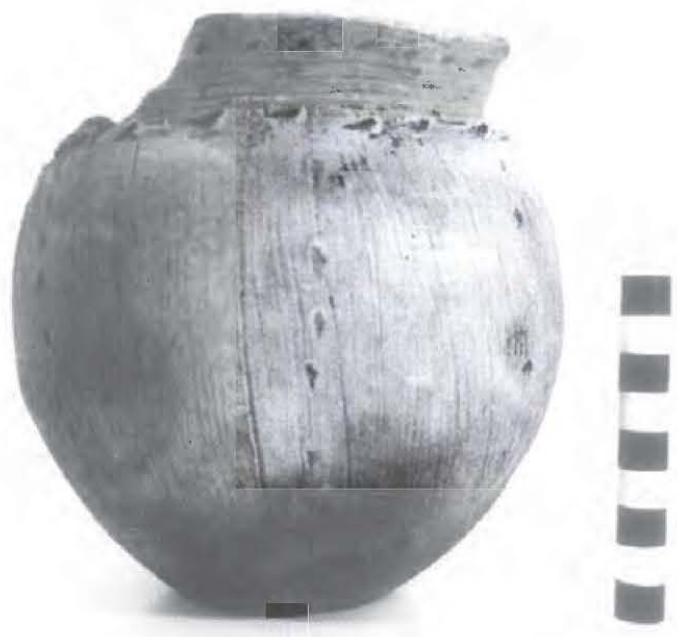

Figure 2. Pease Brushed-Incised jar from the Sipes Hill site.

DECORATION (INCLUDING MOTIF AND ELEMENTS WHEN APPARENT): The rim is decorated with horizontal brushing marks as well as two rows of linear tool punctates pushed through the brushing; the punctated rows are under the lip and at the rim-body juncture. The vessel body is divided into seven vertical panels by vertical rows of tool punctates that extend to the base. The panels are filled with vertical brushing marks that also extend to the vessel base (Figure 2).

PIGMENT USE AND LOCATION ON VESSEL: none

TYPE AND VARIETY [IF KNOWN]: Pease Brushed-Incised 
SITE NAME OR SITE NUMBER: Sipes Hill

VESSEL NO.: 2003.08.1716

NON-PLASTICS AND PASTE: grog

VESSEL FORM: Jar

RIM AND LIP FORM: Direct rim and rounded lip

CORE COLOR: B (fired and cooled in a reducing environment)

INTERIOR SURFACE COLOR: brown; fire clouds on the rim, body, and base

EXTERIOR SURFACE COLOR: brown; fire clouds on the rim, body, and base

WALL THICKNESS (RIM, BODY, AND BASE IN MM): rim, $6.9 \mathrm{~mm}$; body, $10.2 \mathrm{~mm}$; base, $11.0 \mathrm{~mm}$

INTERIOR SURFACE 'TREATMENT: smoothed

EXTERIOR SURFACE TREATMENT: smoothed on the rim

HEIGHT (IN CM): 4.4

ORIFICE DIAMETER (IN CM): 8.4

DIAMETER AT BOTTOM OF RIM OR NECK (IN CM): 8.8

BASE DIAMETER (IN CM) AND SHAPE OF BASE: N/A; circular and tIat

ESTIMATED VOLUME (IN LITERS): 0.22

DECORATION (INCLUDING MOTIF AND ELEMENTS WHEN APPARENT): The vessel rim is plain, but the body has horizontal brushing marks.

PIGMENT USE AND LOCATION ON VESSEL: none

TYPE AND VARIETY [IF KNOWN]: Unidentified utility ware 
SITE NAME OR SITE NUMBER: Sipes Hill

VESSEL NO.: 2003.08.1717

NON-PLAS'IICS AND PASTE: grog

VESSEL FORM: Carinated bowl

RIM AND LIP FORM: Direct rim and a rounded lip

CORE COLOR: $F$ (fired in a reducing environment and cooled in the open air)

INTERIOR SURFACE COL.OR: light brown: fire clouds on the rim, body, and base EXTERIOR SURFACE COLOR: light brown

WALL THICKNESS (RIM, BODY, AND BASE IN MM): rim, $6.1 \mathrm{~mm}$; body, $4.9 \mathrm{~mm}$ INTERIOR SURFACE TREATMENT: smoothed on the rim EXTERIOR SURFACE TREATMENT: smoothed HEIGH'T (IN CM): N/A; rim height is $2.2 \mathrm{~cm}$

ORIFICE DIAMETER (IN CM): 10.0

DIAMETER AT BO'I"IOM OF RIM OR NECK (IN CM): N/A

BASE DIAME'TER (IN CM) AND SHAPE OF BASE: N/A ESTIMATED VOLUME (IN LITERS): N/A

DECORATION (INCLUDING MOTIF AND ELEMENTS WHEN APPARENT): Plain PIGMENT USE AND LOCATION ON VESSEL: none TYPE AND VARIETY [IF KNOWN]: Unidentified plain ware 
SITE NAME OR SITE NUMBER: Sipes Hill

VESSEL NO.: 2003.08.1718

NON-PLASTICS AND PASTE: grog

VESSEL FORM: Carinated bowl

RIM AND LIP FORM: Direct rim and a rounded, exterior folded lip

CORE COLOR: $\mathrm{G}$ (fired in a reducing environment and cooled in the open air)

INTERIOR SURFACE COLOR: grayish-brown; fire clouds on the rim, body, and base

EXTERIOR SURFACE COLOR: light brown; fire clouds on the rim, body, and base

WALL THICKNESS (RIM, BODY, AND BASE IN MM): rim, $4.2 \mathrm{~mm}$

INTERIOR SURFACE TREATMENT: smoothed

EXTERIOR SURFACE TREATMENT: smoothed on the body

HEIGHT (IN CM): 6.7

ORIFICE DIAMETER (IN CM): 16.1

DIAMETER AT BOTTOM OF RIM OR NECK (IN CM): 14.4

BASE DIAMETER (IN CM) AND SHAPE OF BASE: 6.7 ; circular and flat

ESTIMATED VOLUME (IN LITERS): 0.65

DECORATION (INCLUDING MOTIF AND ELEMENTS WHEN APPARENT): The rim has a series of eight horizontal rows of circular tool punctates. The rows are divided into four rim panels by four sets of vertical punctated rows. One set has 10 vertical punctated rows, another has six sets of punctated rows, a third has four punctated rows, and the fourth divider has three vertical punctated rows (Figure 3 ).

PIGMENT USE AND LOCATION ON VESSEL: none

TYPE AND VARIETY [IF KNOWN]: Unidentified utility ware

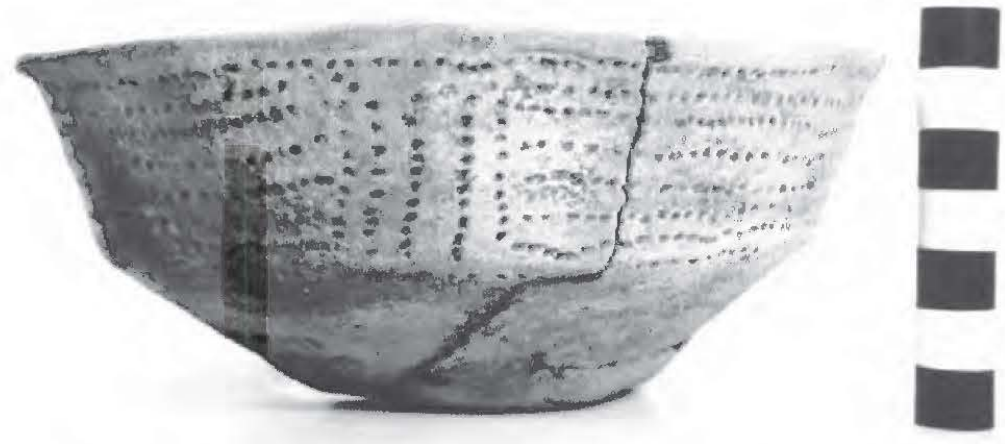

Figure 3. Punctated carinated bowl from the Sipes Hill site. 
SITE NAME OR SITE NUMBER: Sipes Hill

VESSEL NO.: 2003.08.1719

NON-PLASTICS AND PASTE: grog

VESSEL FORM: Compound bowl

RIM AND LIP FORM: Everted rim and rounded lip

CORE COL OR: $\mathrm{F}$ (fired in a reducing environment and cooled in the open air)

INTERIOR SURFACE COLOR: light brown; fire cloud on the base

EXTERIOR SURFACE COLOR: light brown; fire clouds on the rim, body, and base

WALL THICKNESS (RIM, BODY, AND BASE IN MM): rim, $4.2 \mathrm{~mm}$

INTERIOR SURFACE TREATMENT: smoothed

EXTERIOR SURFACE TREATMENT: smoothcd

HEIGHT (IN CM): 7.9

ORIFICE DIAMETER (IN CM): 18.1

DIAMETER AT BOTTOM OF RIM OR NECK (IN CM): 16.6

BASE DIAMETER (IN CM) AND SHAPE OF BASE: 6.7; circular and flat

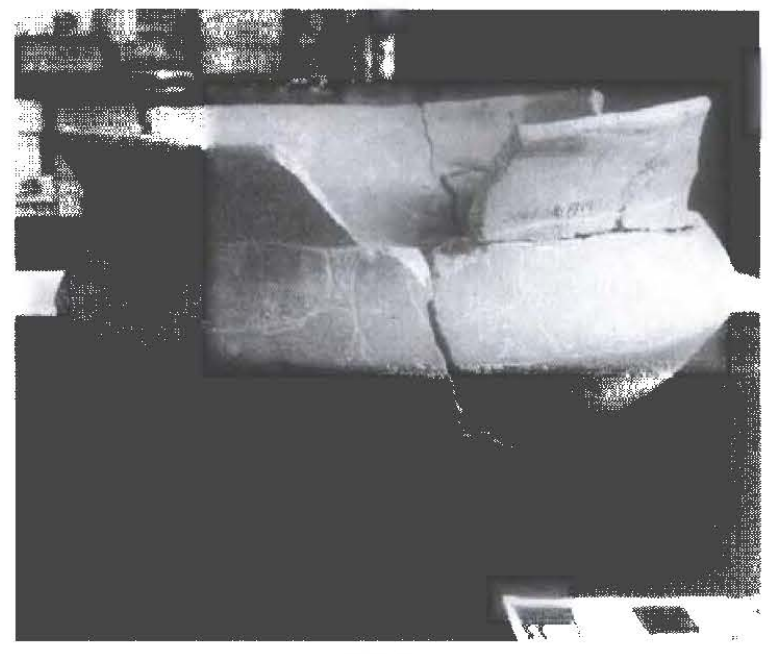

Figure 4. cf. Ripley Engraved, var. unspecified compound bowl from the Sipes Hill site.

ESTIMATED VOLUME (IN LITERS): 1.1

DECORATION (INCLUDING MOTIF AND ELEMENTS WHEN APPARENT): The upper rim panel is plain, but the lower rim panel has a number of nested negative $S$ or SZ engraved elements-executed both sideways and vertically - outlined by excised triangle elements (Figure 4). There are also ovalshaped engraved elements and a hooked arm element with a single excised pendant triangle on the outer part of the hooked arm.

PIGMENT USE AND LOCATION ON VESSEL: red in engraved lines

TYPE AND VARIETY [IF KNOWN]: cf. Ripley Engraved, var. unspecified 
SITE NAME OR SITE NUMBER: Sipes Hill

VESSEL NO.: 2003.08.1720

NON-PLASTICS AND PASTE: grog and hematite

VESSEL FORM: Carinated bowl

RIM AND LIP FORM: Direct rim and rounded lip

CORE COLOR: F (fired in a reducing environment and cooled in the open air)

INTERIOR SURFACE COLOR: dark yellowish-brown

EXTERIOR SURFACE COLOR: dark yellowish-brown

WALL THICKNESS (RIM, BODY, AND BASE IN

MM): rim, $5.9 \mathrm{~mm}$; body, $6.4 \mathrm{~mm}$; base, $7.4 \mathrm{~mm}$

INTERIOR SURFACE TREATMENT: none

EXTERIOR SURFACE TREATMENT: smoothed

HEIGHT (IN CM): 8.9

ORIFICE DIAMETER (IN CM): 14.0

DIAMETER AT BOTTOM OF RIM OR NECK (IN CM): 14.0

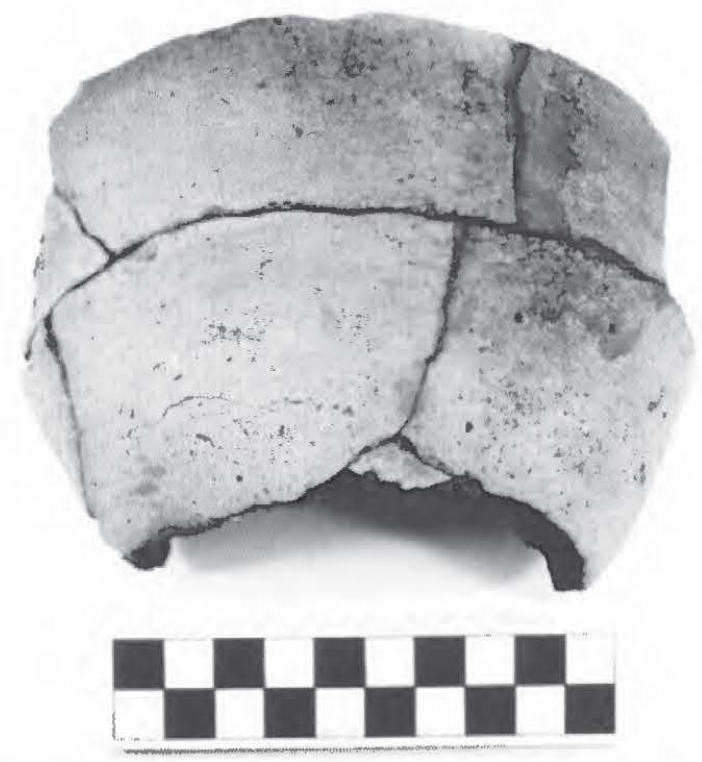

ESTIMATED VOLUME (IN LITERS): 0.75

Figure 5. Plain carinated bowl from the Sipes Hill site.

DECORATION (INCLUDING MOTIF AND ELEMENTS WHEN APPARENT): Plain (Figure 5)

PIGMENT USE AND LOCATION ON VESSEL: none

TYPE AND VARIETY [IF KNOWN]: Unidentified plain ware 
16 Journal of Northeast Texas Archaeology 45 (2014)

SITE NAME OR SITE NUMBER: Sipes Hill

VESSEL NO.: 2003.08.1721

NON-PLASTICS AND PASTE: grog

VESSEL FORM: Compound bowl

RIM AND LIP FORM: Everted rim and rounded lip

CORE COLOR: $\mathrm{H}$ (fired in a reducing environment and cooled in the open air)

INTERIOR SURFACE COLOR: dark yellowish-brown

EXTERIOR SURFACE COLOR: dark grayish-brown

WALL THICKNESS (RIM, BODY, AND BASE IN MM): rim, $4.6 \mathrm{~mm}$

INTERIOR SURFACE TREATMENT: smoothed

EXTERIOR SURFACE TREATMENT: burnished

HEIGHT (IN CM): 9.0

ORIFICE DIAMETER (IN CM): 21.2

DIAMETER AT BOTTOM OF RIM OR NECK (IN CM): 20.4

BASE DIAMETER (IN CM) AND SHAPE OF BASE: 8.9; circular and flat

ESTIMATED VOLUME (IN LITERS): 1.5

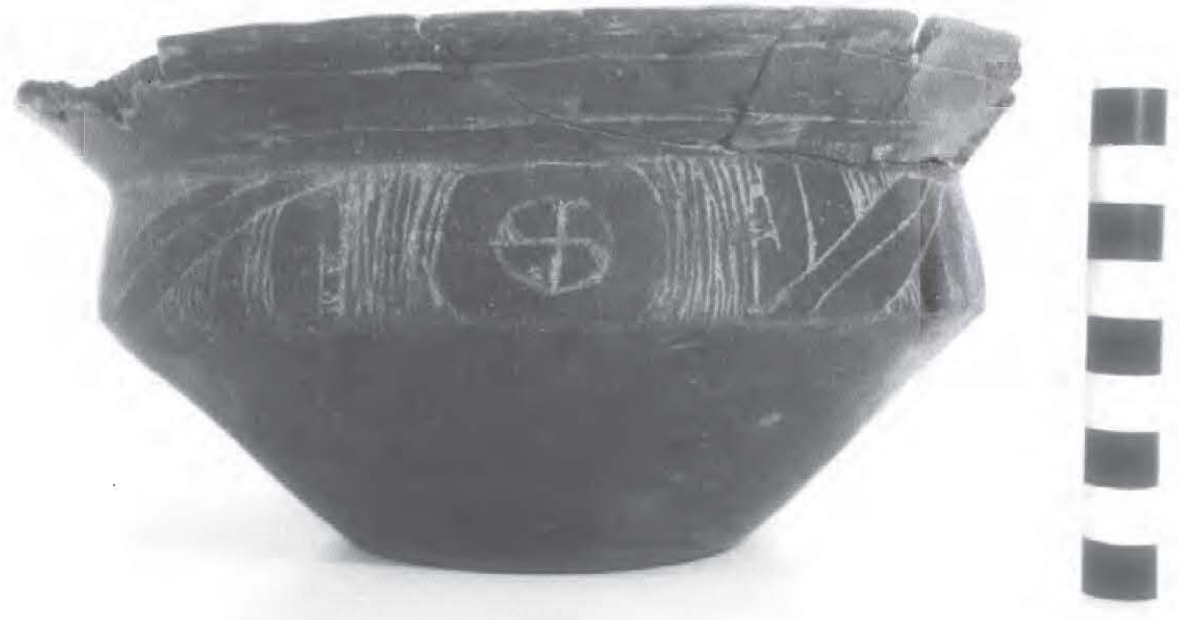

Figure 6. cf. Ripley Engraved, var. unspecified compound bowl from the Sipes Hill site. 
DECORATION (INCLUDING MOTIF AND ELEMENTS WHEN APPARENT): The upper rim panel has three horizontal engraved lines. The lower rim panel has an engraved slanted scroll and circle/rectangular panel motif each alternately repeated two times around the vessel. The central circles or rectangular panel have smaller swastika in circle elements. The circlcs and panels are surrounded by closely-spaced vertical engraved lines, as do the upper and lower scroll fill zones. The scroll fill zoncs also have small sideways engraved brackets and single vertical engraved lines dividing open space between the closely-spaced vertical engraved lines (Figures 6 and $7 a$ ).

PIGMENT USE AND LOCATION ON VESSEL: none

TYPE AND VARIETY [IF KNOWN]: cf. Ripley Engraved, var. unspecified

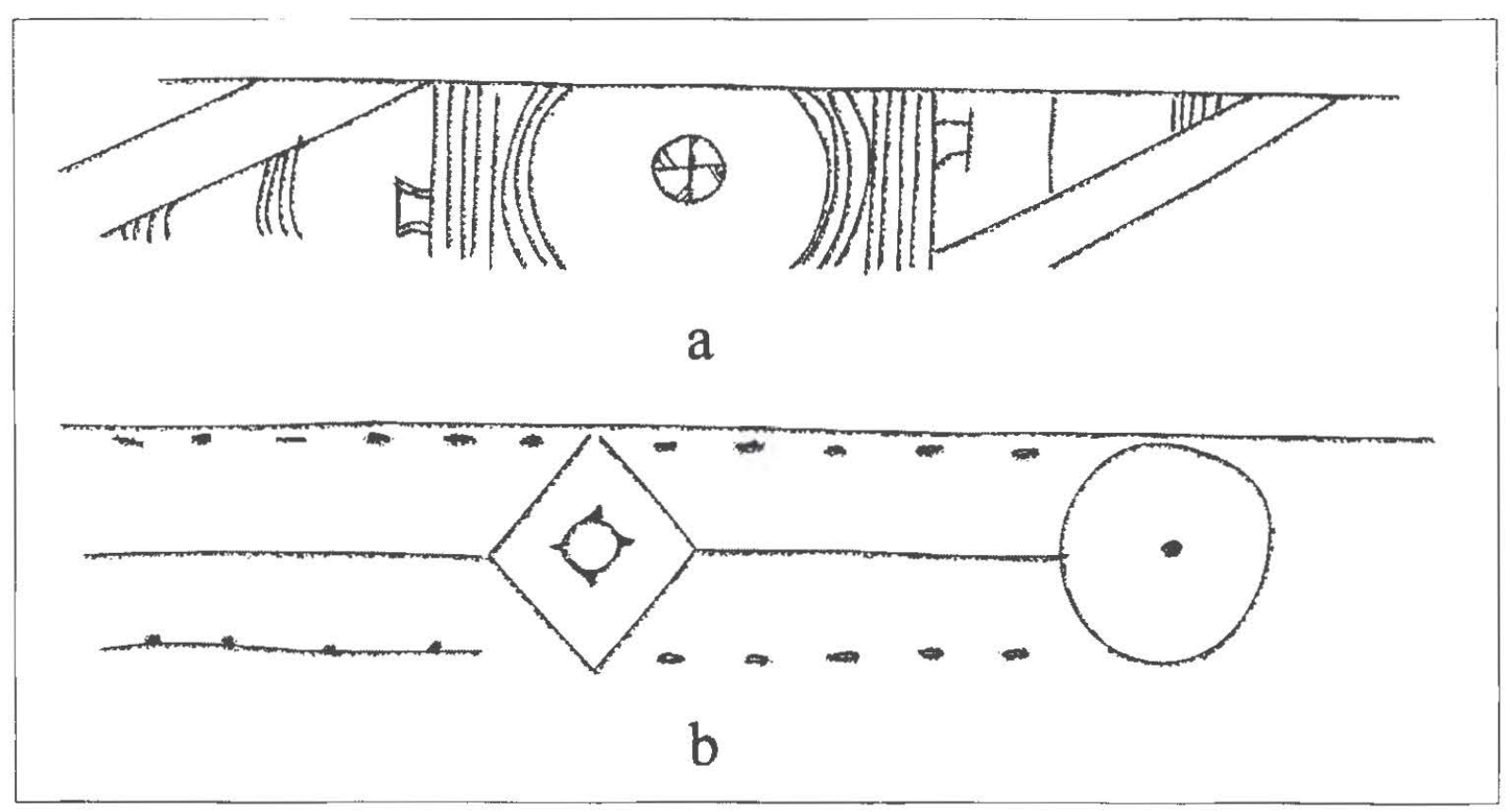

Figure 7. Drawings of engraved motifs of selected Sipes Hill vessels: a, 2003.08.1721; b, 2003.08.1722. 
SITE NAME OR SITE NUMBER: Sipes Hill

VESSEL NO.: 2003.08.1722

NON-PLASTICS AND PASTE: grog and bone

VESSEL FORM: Carinated bowl

RIM AND LIP FORM: Direct rim and rounded, exterior folded lip

CORE COLOR: G (fired in a reducing environment and cooled in the open air)

INTERIOR SURFACE COLOR: dark grayish-brown

EXTERIOR SURFACE COLOR: dark yellowish-brown; fire clouds on the rim, body, and base

WALL THICKNESS (RIM, BODY, AND BASE IN MM): rim, 4.9 mm; body, $5.1 \mathrm{~mm}$; base, $5.1 \mathrm{~mm}$

INTERIOR SURFACE TREATMENT: smoothed

EXTERIOR SURFACE TREATMENT: burnished

HEIGHT (IN CM): 6.4

ORIFICE DIAMETER (IN CM): 16.0

DIAMETER AT BOTTOM OF RIM OR NECK

(IN CM): 15.8

BASE DIAMETER (IN CM) AND SHAPE OF
BASE: N/A

ESTIMATED VOLUME (IN LITERS): 0.59
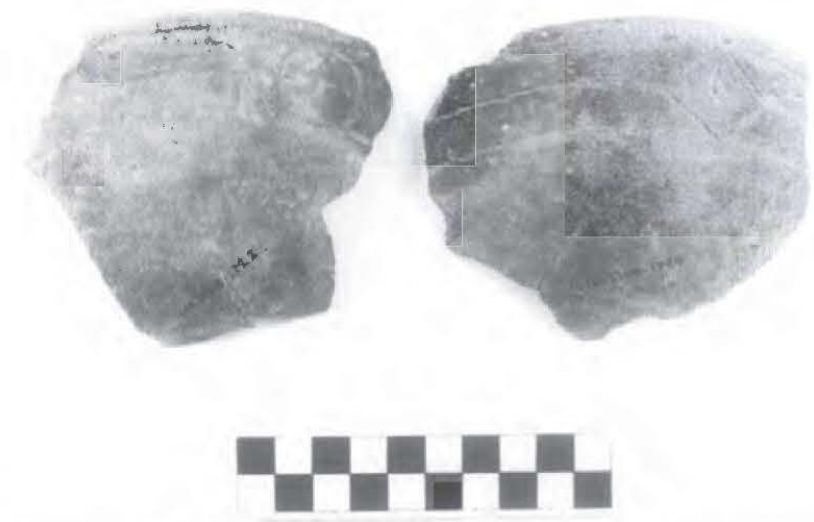

Figure 8. Ripley Engraved, var.McKinney carinated bowl rim sherds from the Sipes Hill site.

DECORATION (INCLUDING MOTIF AND ELEMENTS WHEN APPARENT): The rim panel has a horizontal scroll line with central diamond and circle elements; these elements alternately repeat two times around the vessel. The central diamond element has a smaller and centrally-placed negative oval with excised rays, while the central circle element has a central excised dot. Above and below the scroll lines are excised dashes or small excised pendant triangles (Figures $7 \mathrm{~b}$ and 8 ). There is also an interior horizontal engraved line at the vessel carination.

PIGMENT USE AND LOCATION ON VESSEL: none

TYPE AND VARIETY [IF KNOWN]: Ripley Engraved, var. McKinney 
SITE NAME OR SITE NUMBER: Sipes Hill

VESSEL NO.: 2003.08.1723

NON-PLASTICS AND PASTE: grog

VESSEL FORM: Jar

RIM AND LIP FORM: Direct rim and rounded lip

CORE COLOR: $\mathrm{H}$ (fired in a reducing environment and cooled in the open air)

INTERIOR SURFACE COLOR: dark yellowish-brown

EXTERIOR SURFACE COLOR: dark grayish-brown; organic residue on the rim

WALL THICKNESS (RIM, BODY, AND BASE IN MM): rim, $6.7 \mathrm{~mm}$

INTERIOR SURFACE TREATMENT: smoothed

EXTERIOR SURFACE TREATMENT: none

HEIGHT (IN CM): N/A

ORIFICE DIAMETER (IN CM): 18.0

DIAMETER AT BOTTOM OF RIM OR NECK

(IN CM): 17.9

BASE DIAMETER (IN CM) AND SHAPE OF BASE: N/A

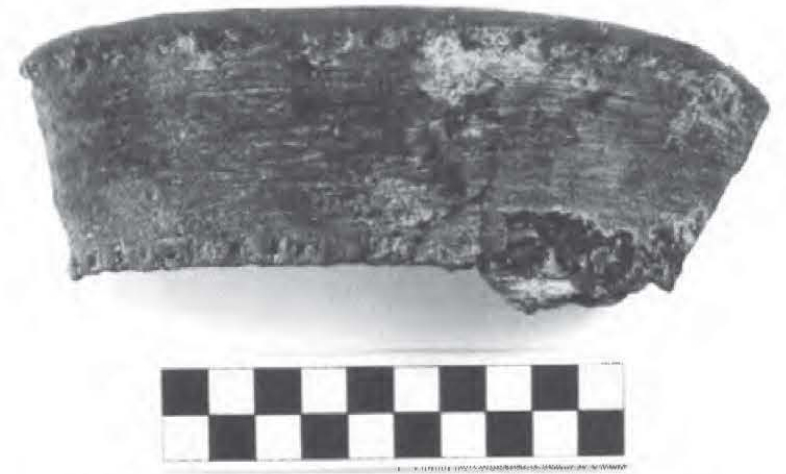

ESTIMATED VOLUME (IN LITERS): N/A

Figure 9. Brushed-punctated jar rim from the Sipes Hill site.

DECORATION (INCLUDING MOTIF AND ELEMENTS WHEN APPARENT): The rim is decorated with horizontal brushing marks, and there are two rows of tool punctations on the rim. One row of punctates is under the lip and the other is at the rim-body juncture (Figure 9).

PIGMENT USE AND LOCATION ON VESSEL: none

TYPE AND VARIETY [IF KNOWN]: Unidentified utility ware 
SITE NAME OR SITE NUMBER: Sipes Hill

VESSEL NO.: 2003.08.1724

NON-PLASTICS AND PASTE: grog

VESSEL FORM: Compound bowl

RIM AND LIP FORM: Everted rim and a rounded lip

CORE COI.OR: F (fired in a reducing environment and cooled in the open air)

INTERIOR SURFACE COLOR: light brown: fire cloud on the basc

EXTERIOR SURFACE COLOR: light brown; fire clouds on the rim, body, and base

WALL THICKNESS (RIM, BODY, AND BASE IN MM): rim, 5.8 mm: body. $6.3 \mathrm{~mm}$; base, $8.9 \mathrm{~mm}$

INTERIOR SURFACE TREATMENT: smoothed

EXTERIOR SURFACE TREATMENT: smoothed

HEIGHT (IN CM): 13.5

ORIFICE DIAMETER (IN CM): 25.7

DIAMETER AT BOTTOM OF RIM OR NECK (IN CM): 23.0

BASE DIAMETER (IN CM) AND SHAPE OF BASE: 5.1 ; circular and flat

ESTIMATED VOLUME (IN LITERS): 2.8

DECORATION (INCLUDING MOTIF AND ELEMENTS WHEN APPARENT): The upper rim panel of this vessel is plain, but the lower rim panel has a slanted scroll and semi-circle engraved motif repcated four times around the vessel. The slanted scrolls meet with upper and lower concentric semi-circles (each with four semi-circles), and there are large excised triangle elements at the juncture of the scrolls and semicircles. There are short vertical and diagonal hatched lines on either side of the slanted scrolls. as well as a central scroll line.

PIGMENT USE AND LOCATION ON VESSEL: white in the engraved lines

TYPE AND) VARIETY [IF KNOWNI: c1. Ripley Engraved, var: unspecified 


\section{SUMMARY AND CONCLUSIONS}

The 10 documented ceramic vessels from the Sipes Hill site include two plain vessels, four utility ware vessels, and four fine warc vessels. All of the vessels are tempered with grog, but two of them (20\%) also have either burned bone or crushed hematite added to the paste. The vessels have been uniformly fired in a low oxygen or reducing environment, but $90 \%$ of them were subsequently cooled in the open air, leaving a thin oxidized surface on one or both vessel cores.

The plain vessels from the Sipes Hill site are small carinated bowls. The utility ware vessels are small to medium-sized jars $(n=3)$ and a carinated bowl. They are decorated with brushed and/or punctated elements, and the jars include one Pease Brushed-Incised vessel. The fine wares are small to medium-sized Ripley Engraved carinated and compound bowls. One is a Ripley Engraved, var. McKinnev vessel with excised pendant triangles and dashes: the pendant triangle motif (Turner 1978; Thurmond 1990:Figure 6; Perttula et al. 2012:Figure 5). The design elements and motifs on the Sipes Hill vessels are consistent with other Titus phase funerary wares from the mid-Sabine River basin (see Fields and Gadus 2012).

This pendant triangle Ripley Engraved motif is thought to be common only in later post-A.D. 1550 Titus phase sites where it is part of the ceramic repertoire of local communities. However, no bowls with the traditional pendant triangle motif are present at the Pine Tree Mound site itself (Fields and Gadus 2012:674), calling into question the community affiliation of the Sipes Hill site, even though it falls within the defined boundaries of the Pine Tree Mound community (Fields and Gadus 2012:Figure 9.10).

\section{ACKNOWLEDGMENTS}

We appreciate the help provided by Patti Haskins of the Gregg County Historical Museum in facilitating the vessel documentation, and thanks to Katie Tadlock for reconstructing several of the vessels from the site for documentation purposes.

\section{REFERENCES CITED}

Fields, R. C. and E. F. Gadus (editors)

2012 Archeology of the Nadaco Caddo: The View from the Pine Tree Mound Site (41HS15), Harrison County, Texas. 2 Vols. Reports of Investigations No. 164. Prewitt and Associates, Inc., Austin.

Perttula, T. K.

2012 The Character of Fifteenth- to Seventeenth-Century Caddo Communities in the Big Cypress Creek Basin of Northeast Texas. In The Archaeology of the Caddo, edited by T. K. Perttula and C. P. Walker, pp. 363-410. University of Nebraska Press, Lincoln.

Perttula, T. K., B. Nelson. and M. Walters

2012 Caddo Archaeology at the Henry Spencer Site (4IUR315) in the Little Cypress Creek Basin of East Texas. Special Publication No. 20. Friends of Northeast Texas Archaeology, Pittsburg and Austin.

Thurmond, J. P.

1990 Archeology of the Cypress Creek Drainage Basin, Northeastern Texas and Northwestern Louisiana. Studies in Archeology 5. Texas Archeological Research Laboratory, The University of Texas at Austin.

Turner, R. L.

1978 The Tuck Carpenter Site and Its Relations to Other Sites within the Titus Focus. Bulletin of the Texas Archeological Society 49:1-110. 